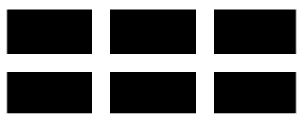

ThE WiLliam DAVIDSON INSTITUTE AT THE UNIVERSITY OF MICHIGAN BUSINESS SCHOOL

Healthy Organizations and the Link to Peaceful Societies: Strategies for Implementing Organizational Change

\author{
By: Jeannette Jackson and Maria Coolican
}

William Davidson Working Paper Number 536

June 2002 


\title{
Healthy Organizations and the Link to Peaceful Societies: Strategies for Implementing Organizational Change
}

\author{
By: \\ Jeannette Jackson \\ jeannettej@aol.com \\ (734) 417-6429 \\ and \\ Maria Coolican \\ mariajc@umich.edu \\ (734) 417-6806
}

Directors, Grosvenor Associates, Inc.

1130 W Washington Street

Ann Arbor, MI 48103

Keywords: organizational behavior; leadership; leadership development; management; human resources; organizational development; change; values 


\section{Healthy Organizations and the Link to Peaceful Societies: Strategies for Implementing Organizational Change}

When designing and implementing an organizational change process, we intentionally and significantly impact the lives of the human beings who make up the organization. Most individuals spend a majority of their time, often at least five days each week, in an organizational setting or framework. If the organization is structured in a way that recognizes the needs of the employees; has a code of behavior — oftentimes referred to as the organizational values - that is civil and caring; uses this code of behavior to give developmental feedback to employees; and, creates opportunities for a variety of networks between people, the environment is very likely to be conducive for healthy organizational growth. If people are expected to behave respectfully and in a civil fashion, and if the organization intentionally promotes such behavior, the continuous, daily reinforcement of a respectful way of working together will often spill out into behavior outside of the organization. If we hope to impact society and the ways in which we all live together, we are obligated to consider how to positively impact the thinking and the behavior of individuals at all stages of life and in a variety of organizational settings. Families, schools, religious organizations, social groups and business organizations all have the potential of contributing to a more peaceful society by creating "rules of the game" that require and intentionally facilitate respectful, civil and peaceful behaviors of their members.

As we seek to structure our working practices with clients who represent a large variety of organizational styles and structures, we continually strive to find innovative and respectful ways that we can help to facilitate positive change. Our goal—indeed, our very ethic - is to create those change processes in such a way so as to recognize and respond to the needs of employees or organizational members, and to help to create the conditions that lead to civil and respectful ways of being.

The focus of our work at the recent Corporate Governance and Sustainable Peace conference is centered on the role that business and other organizational entities can and 
should play in helping to create peaceful and civil societies. We choose to focus our energies on the organizational level, for this is often where people spend a majority of their time and one where there are established — either explicitly or implicitly — codes of behavior that are reinforced over time. When we think about creating momentum toward the ideal of more peaceful and just society, we know it means affecting individuals at a fundamental, personal level. There is additionally, of course, the question of peace and conflict. We believe in the value of healthy conflict as well as in the notion that people often need to learn mechanisms for identifying and dealing with unhealthy conflict. Disputes, differing opinions, divergent values and beliefs and fundamentally different ways of viewing the world are examples of the wonderfully diverse world in which we live; our challenge is to positively harness the energy of these issues and to leverage that energy in our pursuit of peaceful societies.

We come, then, to the essential question: how can organizations best and most appropriately affect human behavior in such a way so that a spillover effect of similarly respectful behaviors into our larger world is most likely to occur? One of the best overall examples of an organization that has "spillover" effects on society is the Pike Street Fish Market in Seattle Washington. The employees transform the experiences that customers and passers-by have through one-on-one interaction and intense showmanship. The employees embody the company values, which support the vision and mission of the company. These values_-Play Together; Be There; Make Their Day; and, Choose Your Attitude - are lived in observable and dynamic ways. It is not surprising, therefore, to find that these values and ways of behaving are infectious and leave the customers feeling as though they, too, have the possibility of living their lives in similarly positive ways.

Pike Street uses these values to guide their everyday actions and behaviors that make the vision of being "the greatest fish market in the world" come alive. The employees interpret the values individually; for example, no one tells them exactly how to "play together" or "be there" or "make their day". They choose. There is a tremendous sense of personal freedom in this choice. Interestingly, it is the focus on the small actions and the specific attitudes and behaviors of the employees, that appears to create such a vibrant 
and successful company. Our experience with similar organizations is that it is the everyday actions in which each employee is willing to engage that makes the organizational vision a reality.

Our belief is that the world cannot be changed until a significant majority of individuals in the world are encouraged to move in this direction. If one looks at the world as a whole it is made up of millions of organizations from the largest political unit to the smallest family or tribe. The core question for us in our work is how to have an impact on the individuals within these organizations. It is the rare individual who is completely on his or her own and without significant organizational contact. In our work with the Corporate Governance and Sustainable Peace conference, we choose to focus on the unit of the business organization. Business organizations are responsible for millions of individuals who often work almost half their waking hours within such a structure. If we believe that one's environment has a significant and lasting impact on one's behavior and choices, it then becomes obvious that the business organization is an entity that can provide the organizational structure and social leadership to help shape positive individual behaviors.

There are a few key areas in which an organization can explicitly promote some of these positive behaviors. Organizational leadership is, perhaps, the most important of these areas. What the leader says and holds people accountable for is critical in whether people believe in the goals and values of the organization. The leader must be willing to make the hard decisions about people who do not uphold the goals and values of the organization. Through the identification of those organizational goals and values, people learn the norms of the organization and what is expected from them in terms of work content and behavior.

Second, the ways in which organizational structure and value the feedback process can have a powerful effect on people. This is the key tool for influencing behavior on the job as it is directly related to monetary and psychological rewards and consequences. Evaluations are best accomplished when they are framed as a developmental experience. 
In addition, we find that individuals can accept feedback much more readily when they understand the psychological response to feedback, when they are asked to evaluate themselves as a part of the process and when they trust the individual giving them the feedback. At a leadership or board or directors level, the process of self-evaluation is a critical piece of the feedback process. We have seen success at this level by framing the self-appraisal as a positive, non-threatening, collegial and growth-oriented procedure.

Third, the area of conflict resolution is one that has huge potential for modeling appropriate and ethical behaviors. Many people do not have the skills to navigate conflict and business has an opportunity to shape how people react to and manage conflict situations. How individuals manage, discuss and learn from conflict has everything to do with organizational culture, and closely reflects the organizational values. Conflict resolution is heavily based on the construct of trust. Trust, in turn, is based heavily on the depth of relationship and sense of safety. Knowing, for example, that one will have to see someone again and again and again makes a difference in how one chooses to behave. We believe this has implications for creating opportunities for employees, customers, and community members to meaningfully connect.

We find particularly powerful energy around the fourth core area in which organizations can explicitly influence behavior, that of creating and facilitating "small wins" within an organization. Weick's (1984) framework of how small wins can generate energy and lead to significant organizational change is one way to think about how to engage the organization in what is important. According to Weick, a small win is "a concrete, complete, implemented outcome of moderate importance." We choose to think about and use this construct as being less about social problems and more about social growth and the creation of healthy organizations that impact people's behavior.

Finally, the notion of respectful attention to human needs within an organizational setting is one of the most powerful ways that organizations can facilitate positive behavior. Based largely on the work of Maslow, we know that it is only when we meet people's basic needs that they can then focus on higher and more cognitive levels of operation. 
We are all a blend of our personal and professional lives and if the business shows caring and concern for personal circumstances while still holding people accountable for results in a reasonable way, the business is likely to build a strong sense of loyalty. This building of community is what often keeps people at a job even when they may not care for the content of the work or for the wages.

The pursuit of peaceful ways of living together is one that is at the very core of who we are as an organization and what we strive for every day as we work with a wide variety of clients. By making this pursuit explicit, and by examining the ways in which organizational structures and practices can be designed and developed to positively impact human behavior, we have the possibility-indeed, the very strong and energizing possibility—of contributing to a peaceful, productive and energizing world. 
William Davidson Institute Working Paper 536

\section{References}

Weick, Karl E. (1984). Small Wins: Redefining the Scale of Social Problems, American Psychology 39(1):40-49. 


\section{DAVIDSON INSTITUTE WORKING PAPER SERIES - Most Recent Papers}

The entire Working Paper Series may be downloaded free of charge at: www.wdi.bus.umich.edu

CURRENT AS OF $1 / 17 / 03$

\begin{tabular}{|c|c|c|}
\hline Publication & Authors & Date \\
\hline $\begin{array}{l}\text { No. 536: Forthcoming in Vanderbilt Journal of Transnational Law, } \\
\text { "Healthy Organizations and the Link to Peaceful Societies: Strategies } \\
\text { for Implementing Organizational Change" }\end{array}$ & $\begin{array}{l}\text { Jeannette Jackson and Maria } \\
\text { Coolican }\end{array}$ & Jan. 2003 \\
\hline $\begin{array}{l}\text { No. 535: Forthcoming in Vanderbilt Journal of Transnational Law, } \\
\text { "Workplace Violence and Security: Are there Lessons for } \\
\text { Peacemaking?" }\end{array}$ & $\begin{array}{l}\text { Frances E. Zollers and Elletta } \\
\text { Sangrey Callahan }\end{array}$ & Jan. 2003 \\
\hline $\begin{array}{l}\text { No. 534: Forthcoming in Vanderbilt Journal of Transnational Law, } \\
\text { "700 Families to Feed: The Challenge of Corporate Citizenship" }\end{array}$ & Tara J. Radin & Jan. 2003 \\
\hline $\begin{array}{l}\text { No. 533: Forthcoming in Vanderbilt Journal of Transnational Law, } \\
\text { "Governing for Genuine Profit" }\end{array}$ & Michael J. O'Hara & Jan. 2003 \\
\hline $\begin{array}{l}\text { No. 532: Forthcoming in Vanderbilt Journal of Transnational Law, } \\
\text { "Adapting Corporate Governance for Sustainable Peace" }\end{array}$ & $\begin{array}{l}\text { Timothy L. Fort and Cindy A. } \\
\text { Schipani }\end{array}$ & Jan. 2003 \\
\hline $\begin{array}{l}\text { No. 531: Forthcoming in Vanderbilt Journal of Transnational Law, } \\
\text { "Groundings of Voice in Employee Rights" }\end{array}$ & Dana Muir & Jan. 2003 \\
\hline $\begin{array}{l}\text { No. 530: Forthcoming in Vanderbilt Journal of Transnational Law, } \\
\text { Gender Voice and Correlations with Peace }\end{array}$ & $\begin{array}{l}\text { Morehead Dworkin and Cindy A. } \\
\text { Schipani }\end{array}$ & Jan. 2003 \\
\hline $\begin{array}{l}\text { No. 529: Forthcoming in Vanderbilt Journal of Transnational Law, } \\
\text { "The Organizational Model for Workplace Security" }\end{array}$ & Dr. Thomas K. Capozzoli & Jan. 2003 \\
\hline $\begin{array}{l}\text { No. 528: Forthcoming in Vanderbilt Journal of Transnational Law, } \\
\text { "Nationbuilding 101: Reductionism in Property, Liberty, and Corporate } \\
\text { Governance" }\end{array}$ & O. Lee Reed & Jan. 2003 \\
\hline $\begin{array}{l}\text { No. 527: Forthcoming in Vanderbilt Journal of Transnational Law, "On } \\
\text { Virtue and Peace: Creating a Workplace Where People Can Flourish" }\end{array}$ & $\begin{array}{l}\text { Caryn L. Beck-Dudley and } \\
\text { Steven H. Hanks }\end{array}$ & Jan. 2003 \\
\hline $\begin{array}{l}\text { No. 526: Forthcoming in Vanderbilt Journal of Transnational Law, } \\
\text { "Novartis and the United Nations Global Compact Initiative" }\end{array}$ & Lee A. Tavis & Dec. 2002 \\
\hline $\begin{array}{l}\text { No. 525: Why Transition Paths Differ: Russian and Chinese Enterprise } \\
\text { Performance Compared }\end{array}$ & Sumon Bhaumik and Saul Estrin & Jan. 2003 \\
\hline $\begin{array}{l}\text { No. 524: Official Regulations and the Shadow Economy: A Labour } \\
\text { Market Approach }\end{array}$ & Maxim Bouev & Dec. 2002 \\
\hline No. 523: Children at Risk: Infant and Child Health in Central Asia & Cynthia Buckley & Jan. 2003 \\
\hline No. 522: Wages and International Rent Sharing in Multinational Firms & $\begin{array}{l}\text { John W. Budd, Jozef Konings and } \\
\text { Matthew J. Slaughter }\end{array}$ & July 2002 \\
\hline $\begin{array}{l}\text { No. 521: Gross Job Flows in Ukraine: Size, Ownership and Trade } \\
\text { Effects }\end{array}$ & $\begin{array}{l}\text { Jozef Konings, Olga Kupets and } \\
\text { Hartmut Lehmann }\end{array}$ & Dec. 2002 \\
\hline $\begin{array}{l}\text { No. 520: Entrepreneurial Networking in China and Russia: Comparative } \\
\text { Analysis and Implications for Western Executives }\end{array}$ & Bat Batjargal & Dec. 2002 \\
\hline $\begin{array}{l}\text { No. 519: Agriculture and Income Distribution in Rural Vietnam under } \\
\text { Economic Reforms: A Tale of Two Regions }\end{array}$ & $\begin{array}{l}\text { Dwayne Benjamin and Loren } \\
\text { Brandt }\end{array}$ & Mar. 2002 \\
\hline $\begin{array}{l}\text { No. 518: Property Rights, Labour Markets, and Efficiency in a } \\
\text { Transition Economy: The Case of Rural China }\end{array}$ & $\begin{array}{l}\text { Dwayne Benjamin and Loren } \\
\text { Brandt }\end{array}$ & Mar. 2002 \\
\hline $\begin{array}{l}\text { No. 517: Bank Discrimination in Transition Economies: Ideology, } \\
\text { Information or Incentives? }\end{array}$ & Loren Brandt and Hongbin Li & Oct. 2002 \\
\hline $\begin{array}{l}\text { No. 516: Ex-ante Evaluation of Conditional Cash Transfer Programs: } \\
\text { The Case of Bolsa Escola }\end{array}$ & $\begin{array}{l}\text { François Bourguignon, Francisco } \\
\text { H. G. Ferreira and Phillippe G. } \\
\text { Leite }\end{array}$ & Sep. 2002 \\
\hline No. 515: Missed Expectations: The Argentine Convertibility & $\begin{array}{l}\text { Sebastian Galiani, Daniel } \\
\text { Heymann and Mariano Tommasi }\end{array}$ & Nov. 2002 \\
\hline $\begin{array}{l}\text { No. 514: Job Reallocation and Productivity Growth under Alternative } \\
\text { Economic Systems and Policies: Evidence from the Soviet Transition }\end{array}$ & J. David Brown and John S. Earle & Nov. 2002 \\
\hline $\begin{array}{l}\text { No. 513: Cross-Border Trading as a Mechanism for Capital Flight: } \\
\text { ADRs and the Argentine Crisis }\end{array}$ & $\begin{array}{l}\text { Sebastian Auguste, Kathryn M.E. } \\
\text { Dominguez, Herman Kamil and } \\
\text { Linda L. Tesar }\end{array}$ & Nov. 2002 \\
\hline $\begin{array}{l}\text { No. 512: Embracing the Market: Entry into Self-Employment in } \\
\text { Transitional China, } 1978-1996\end{array}$ & Xiaogang $\mathrm{Wu}$ & Sep. 2002 \\
\hline
\end{tabular}

